\title{
Eksistensi Viktimologi dalam Penyelesaian Ganti Rugi
}

\author{
Sri Suhartati Astoto
}

\begin{abstract}
Victim those person who are thereatened or destroyed by an act or ommision of another (man, structure, organization or institusion) and consequently, a punishible act (not only criminal act but also other punishable acts as misdemeanors, economic offeneses, non fulfilment or work duties) or from an accident (accident at work, at home, traffic accident, etc). Suffering may becaused by anbother man (man-made victim) nother structure where people are also involed.
\end{abstract}

\section{Pendahuluan}

Ketika maraknya berbagai kasus kejahatan yang mencuat di Indonesia, acapkali dilihat kasus tersebut hanya dari perspektif kepentingan umum dalam hal ini dilakukan oleh negara. Kalaupun kasus kejahatan didekati dari segi kepentingan korban kejahatan, tetapi hal itu belum menyentuh pada aspek ganti rugi bagi pihak korban. Artinya penyelesaian hukum sifatnya hanya dari hukum pidana saja.

Padahal kenyataannya sekarang ini, ilmu yang berbicara tentang kepentingan korban akibat kejahatan sudah berkembang dengan pesat. Aspek perdata sedang menjadi perhatian serius. Implementasi kongkrit dari fokus ini adalah mengkaitkan antara eksistensi viktimologi dalam pelaksanaan ganti rugi.

Beberapa alasan yang memperkuat relasi keduanya, yakni bahwa ketika kesepakatan para pihak merupakan hal yang penting agar tidak terjadinya korban karena kedua belah pihak harus menyatakan secara bebas kehendaknya dalam menentukan besarnya uang ganti rugi dan jika kehendak ini tidak dinyatakan secara bebas timbul cacat kehendak dan cacat kehendak ini timbul akibat adanya penyalahgunaan kekuasaan yang menyebabkan timbulnya korban, disinilah kaitan eksistensi viktimologi dengan penyelesaian pelaksanaan ganti rugi.

\section{Makna, Perkembangan, dan Manfaat Viktimologi}

Viktimologi berasal dari kata-kata Latin Victima yang berarti korban dan logos yang berarti pengetahuan ilmiah/studi. ${ }^{1} \mathrm{Jadi}$ viktimologi dapat diartikan sebagai suatu

'Gosita, Arif. 1987. Victimologi dan KUHP Yang Mengatur Ganti Kerugian Pihak Korban. Jakarta: Akademika Presindo. Him. 40. 
bidang iimu pengetahuan yang mengkaji semua aspek yang berkaitan dengan korban.

Perumusan ini membawa akibat suatu victimasi yang harus dipahami sebagai berikut: a).Korban akibat perbuatan manusia, Korban akibat perbuatan manusia dapat menimbulkan perbuatan kriminal (misalnya korban kejahatan perkosaan, korban kejahatan politik) dan yang bersifat non kriminal (perbuatan perdata) misalnya korban dalam ganti rugi tanah, korban dalam bidang administratif dan lain-lain sebagainya.; b). Korban di luar perbuatan manusia, Korban akibat di luar perbuatan manusia seperti bencana alam dan sebagainya. ${ }^{2}$

Pengertian korban yang mendasari lahirnya kajian viktimologi pada awalnya terbatas pada korban kejahatan. Dengan demikian tanpa mengecilkan arti dari upaya pengkajian korban selain dari korban kejahatan di dalam masyarakat, maka dalam tulisan ini memfokuskan korban dalam pengertian viktimologi, bukan saja korban kejahatan, tetapi juga ada korban dalam artian perdata.

Sebagaimana yang dijelaskan Separovic, perkembangan viktimologi sudah sampai pada fase ketiga. Adanya perkembangan viktimologi merupakan suatu hasil interaksi akibat inter relasi antara fenomena yang ada dan saling mempengaruhi. ${ }^{3}$

Pada hakekatnya yang paling penting adalah mencari fenomena yang relevan, yang mempengaruhi pengembangan viktimologi, yang menjadi partisipan pendukung atau penghambat pengembangan viktimologi di suatu negara. Salah satu faktor pendukung utama yang mempengaruhi pengembangan viktimologi di suatu negara adalah pandangan hidup tertentu bangsa negara tersebut. Diharapkan adanya keserasian dan keselarasan antara pandangan hidup tersebut, dengan viktimologi dapat diterima.

Viktimologi dapat dirumuskan sebagai suatu studi yang mempelajari masalah korban, penimbul korban serta akibat-akibat penimbul korban yang merupakan suatu masalah sebagai suatu kenyataan sosial. $\mathrm{Di}$ sini yang dimaksud dengan korban dan yang menimbulkan korban dapat berupa individu/ masyarakat. Sedangkan yang dimaksud dengan akibat-akibat penimbul korban adalah setiap tindakan terhadap pihak korban dan atau pihak pelaku serta mereka yang secara langsung atau tidak langsung terlibat dalam terjadinya suatu peristiwa.

Ada tiga fase perkembangan viktimologi dalam mengkaji permasalahan korban dengan segala aspeknya. Pada awalnya, viktimologi hanya mempelajari korban kejahatan saja. Pada fase ini dikatakan sebagai Penal or Special Victimiology. Pada fase kedua, viktimologi tidak hanya mengkaji masalah korban kejahatan saja, tetapi juga meliputi korban kecelakaan. Pada fase ini disebut sebagai General Victimology. Fase ketiga, viktimologi telah berkembang lebih luas lagi yaitu mengkaji permasalahan korban karena penyalahgunaan kekuasaan dan hak asasi manusia. Fase ini disebut sebagai $\mathrm{New}$ Victimology (Separovic). ${ }^{4}$

\footnotetext{
2J.E. Sahetapy. 1987. Victimologi. Jakarta. Pustaka Sinar Harapan. HIm. 35.

${ }^{3}$ Arif Gosita. 1983. Masalah Korban Kejahatan. Edisi 1. Jakarta: Akademika Pressindo. HIm. 29.

${ }^{4}$ Separovic. 1985. Victim's. USA: D.C. Health and Company. HIm. 29.
} 
Zvonirmeir Paul Separovic memberikan pengertian korban sebagai berikut:

Victin those person who are thereatened or destroyed by an act or ommision of another (man, structure, organization or institusion) and consequently, a victim would by a anyone who has suffered from or been threatened by a punishible act (not only criminal act but also other punishable acts as misdemeanors, economic offeneses, non fulfilment or work duties) or from an accident (accident at work, at home, traffic accident, etc). Suffering may becaused by anbother man (man-made victim) nother strecture where people are also involed (Separovic, 1985 : 139).

Dari pengertian tersebut di atas, korban merupakan orang yang mengalami penderitaan karena sesuatu hal yang meliputi perbuatan orang lain, institusi atau lembaga dan struktur. Yang dapat menjadi korban tidak hanya manusia saja, tetapi dapat pula perusahaan, negara, asosiasi, keamanan, kesejahteraan umum dan agama. Dengan demikian dapat dikatakan bahwa siapa saja dapat menjadi atau menimbulkan korban. Dengan kata lain semua orang potensial untuk menjadi korban dan sebaliknya pula semua orang dapat menimbulkan korban.

Kemudian sejak viktimologi diperkenalkan sebagai suatu ilmu pengetahuan yang mengkaji permasalahan korban serta segala aspeknya, maka Wolfgang melalui penelitiannya menemukan bahwa korban turut serta atau berperan di dalam terjadinya suatu kejahatan. ${ }^{5}$

Menurut Sellin and Wolfgang, ada. beberapa tipologi korban yaitu:

1. Primary VIctimization, adalah korban individual/perorangan, bukan kelompok.

2. Secondary Victimization, korbannya adalah kelompok, misalnya Badan Hukum.

3. Tertiary Victimization, yang menjadi korban adalah masyarakat luas.

4. No Victimization, korbannya tidak dapat segera diketahui, misalnya konsumen yang tertipu dalam menggunakan hasil suatu produksi.

Dari uraian tipologi korban di atas, dapat diketahui bahwa pemikiran tentang victimisasi, hanya berpikir tentang orang-orang yang menimbulkan korban dan yang menjadi korban, merupakan pemikiran yang sempit, kasus-kasus tanah, maka tidak hanya diasumsikan adanya victimisasi orang terhadap orang, tetapi juga suatu victimisasi yang struktural.

Victimisasi struktural pada hakekatnya merupakan tindakan individu yang dilakukan sendiri atau bersama-sama dengan orang lain sebagai unsur suatu kelompok tertentu. Individu ini bersikap dan bertindak berdasarkan tuntutan unsur-unsur struktural sosial tertentu yang membudaya. Unsur-unsur struktural sosial tersebut adalah kepentingan lembaga nilai sosial, norma, status dan peranan. ${ }^{6}$

5Wolfgang. 1979. "Justice for Victim's of Crime." Presented at a Seminar on Criminologi at Indonesia. HIm. 3.

${ }^{6}$ Arif Gosita.Op. Cit. HIm. 140. 
Kemudian dari pendapat Arif Gosita tersebut di atas jika dikaitkan dengan "unsurunsur struktur sosial tersebut dapat mempengaruhi kasus-kasus pengembangan suatu victimisasi yang berkaitan dengan unsurunsur struktur sosial tertentu di mana ia berada. Sebaliknya individu tersebut dalam arti menangani dan memanipulasi unsur-unsur struktur sosial yang sesuai dengan kemampuannya dan kehendak yang bersangkutan.

Dalam rangka memberikan pelayanan terhadap korban perlu diperhatikan manfaat pandangan-pandangan Viktimologi sebagai dasar bersikap dan bertindak 'melakukan pelayanan terhadap korban. Adapun manfaat viktimologi menurut Arief Gosita antara lain: Pertama, viktimologi mempelajari hakekat siapa itu korban dan yang menimbulkán korban; Kedua, viktimologi memberikan sumbangan terhadap korban akibat tindakan manusia yang menimbulkan penderitaan mental, fisik, sosial. Tujuannya tidaklah untuk menyanjung-nyanjung pihak korban, tetapi hanya untuk memberikan beberapa penjelasan mengenai kedudukan dan peran korban serta hubungannya dengan pihak lain. Kejelasan ini sangat penting dàlam rangka mengusahakan kegiatan pencegahan terhadap berbagai macam victimisasi, dengan menegakkan keadilan dan meningkatkan kesejahteraan mereka yang terlibat langsung atau tidak langsung dalam eksistensi suatu victimisasi. Terutama dalam bidang penyuluhan dan pembinaan untuk tidak menjadi korban struktural atau non struktural; Ketiga, viktimologi memberi keyakinan bahwa setiap individu mempunyai hak dan kewajiban untuk mengetahui, mengenali bahaya yang dihadapinya berkaitan dengan kehidupan pekerjaan mereka. Tujuannya bukan untuk menakut-takuti akan tetapi untuk memberikan pengertian yang baik dan agar waspada serta mengusahakan hidup aman seseorang yang meliputi pengetahuan yang seluas-luasnya mengenai bagaimana menghindarinya. Pandangan-pandangan, pernyataanpernyataan dalam viktimologi adalah sangat berharga dalam hal ini. Permasalahan utama viktimologi antara lain adalah mencapai, mengusahakan hasil-hasil yang praktis (pratical), yang berarti menyelamatkan orang dalam bahaya dari bahaya.

Keempat, viktimologi juga memperhatikan permasalahan victimisasi yang tidak langsung misalnya, efek politik ada penduduk "dunia ketiga" akibat penguapan oleh korporasi transnasional, akibat-akibat sosial pada setiap orang akibat polusi industri, terjadinya victimisasi ekonomi, politik dan sosial setiap kali seseorang pejabat menyalahgunakan jabatannya dalam pemerintahan untuk keuntungan diri sendiri (korupsi). Dengan demikian kemungkinan menentukan asal mula victimisasi, mencari sarana menghadapi suatu kasus mengetahui terlebih dahulu kasus-kasus (antisipasi), mengatasi akibat yang merusak; Kelima, viktimologi memberikan dasar pemikiran untuk mengatasi masalah kompensasi pada korban, pendapat-pendapat victimologis digunakan dalam keputusan-keputusan peradilan dan reaksi pengadilan terhadap perilaku kriminal. Mempelajari korban dari dan dalam proses peradilan kriminal, merupakan juga suatu studi mengenai hak-hak asasi manusia. ${ }^{\text {? }}$

'/bid. HIm. 14 
Dari yang telah dikemukakan tersebut di atas sedikit banyaknya dapat diketahui bahwa manfaat dan tujuan viktimologi salah satu diantaranya meringankan kepedihan dan penderitaan yang dialami manusia di dunia. Penderitaan dalam arti menjadi korban jangka pendek dan korban jangka panjang yang berupa kerugian fisik, mental atau moral, sosial ekonomis, kerugian yang hampir sama sekali dilupakan, diabaikan oleh kontrol sosial, yang melembaga seperti penegak hukum, pengadilan dan lain sebagainya.

\section{Korban Dalam Ganti Rugi}

Dalam pelaksanaan ganti rugi pihak-pihak yang menjadi korban tidak selalu orang perorangan, tetapi bisa juga terjadi pada suatu kelompok, badan hukum, atau organisasi. ${ }^{8}$

Di dalam prakteknya berbagai bentuk korban yang timbul dalam pelaksanaan ganti rugi mengakibatkan penderitaan, kerugian mental dan sosial, tidak dapat dijangkau oleh undang-undang atau peraturan yang ada, karena belum dirumuskan terlebih dahulu.

Sebagai dasar pembahasan lebih lanjut yang ingin dipakai perumusan korban adalah sebagai berikut :

Korban adalah mereka (orang) yang menderita jasmaniah dan rohaniah (baik menderita fisik, mental, sosial) sebagai akibat dari tindakan orang lain dalam pelaksanaan ganti rugi tanah yang bertentangan dengan kepentingan dan hak asasi pemilik tanah.
Adapun yang dimaksud dengan mereka (orang) adalah: a).korban orang perorangan atau korban individual (victimisasi primair); b) korban yang bukan orang perorangan misalnya Badan Hukum (perusahaan, pengusaha), organisasi, lembaga.

Pihak korban adalah impersonal. komersial, kolektif (victimisasi sekunder) adalah keterlibatan umum, keserasian sosial dan pelaksanaan perintah misalnya pelanggaran peraturan dan ketentuanketentuan negara. ${ }^{9}$

Menurut Arif Gosita, korban itu timbul sebagai interaksi akibat adanya interrelasi antara fenomena-fenomena yang ada dan saling mempengaruhi. Bila berbicara mengenai kedudukan korban dalam pelaksanaan ganti rugi akan menyinggung peranan serta hak dan kewajiban korban dalam terjadinya ganti rugi sebelumnya telah disinggung peranan si korban yang akan mempengaruhi penilaian dan penentuan hak dan kewajiban korban dalam suatu pelaksanaan ganti rugi serta penyelesaiannya. Korban mempunyai peranan dan tanggungjawab yang fungsional dalam pembuatan dirinya sebagai korban. Yang menjadi pertimbangan penentuan hak dan kewajiban si korban adalah taraf keterlibatan dan tanggung jawab fungsional si korban dalam ganti rugi.

Menurut Arif Gosita hak-hak korban secara ưmum antara lain:

8/bid. HIm. 101.

9lbid. 
1) Korban berhak mendapatkan kompensasi atas penderitaannya, sesuai dengan kemampuan memberi kompensasi si pembuat korban dan taraf keterlibatan/partisipasi/peranan si korban dalam terjadinya ganti rugi dan penyimpanan tersebut.

2) Berhak menolak kompensasi untuk kepentingan pembuat korban (tidak mau diberi kompensasi karena tidak memerlukannya).

3) Berhak mendapatkan kompensasi untuk ahli warisnya bila korban meninggal dunia karena tindakan tersebut.

4) Berhak mendapat pembinaan dan rehabilitasi

5) Berhak mendapat kembali hak miliknya

6) Berhak menolak menjadi saksi bila hal ini akan membahayakan dirinya.

7) Berhak mendapatkan perlindungan dari ancaman pihak pembuat korban bila melapor dan menjadi saksi.

8) Berhak mendapatkan bantuan penasehat hukum, berhak menggunakan upaya hukum. ${ }^{10}$

Jika diperhatikan hak-hak korban tersebut di atas dengan pelaksanaan ganti rugi korban dapat membawa permasalahannya ke pengadilan, maka harus tersedia kemungkinan untuk memperoleh bantuan hukum (Penasehat Hukum) secara cumacuma bagi mereka yang tidak mampu. Sementara itu untuk para korban yang mengalami penderitaan fisik maupun psikis harus pula tersedia fasilitas untuk menampung pengobatan mereka. Khusus untuk mereka yang mengalami tekanan batin seharusnya dapat disediakan pula fasilitas khusus dalam penanganan oleh para ahli. Dalam proses peradilan perdata kedudukan korban sebagai pihak dalam perkara haruslah mendapatkan perlakuan yang wajar.

Pada hakekatnya tidak selamanya korban mau atau sanggup untuk memperjuangkan hak-haknya melalui peradilan, dalam keadaan seperti ini perlu digali dan dikembangkan upaya-upaya hukum adat yang mampu menyelesaikan sengketa ini melalui prosedur perdamaian (Conciliation procedures). Dalam sistem hukum untuk menghormati hak korban. maka permintaan korban untuk menyelesaikan semacam ini perlu diperhatikan dan sedapat mungkin dipenuhi. Apabila pendekatan yang dipakai dalam menangani masalah korban ini adalah dengan "Optik Korban" (dari sudut pandang korban dan bukan dari sudut pandang alat penegak hukum ataupun offender centered), seharusnyalah permintaan korban tentang cara yang diinginkannya dalam menyelesaikan masalah yang mengakibatkan penderitaan baginya diberikan perhatian utama."

Kemudian menurut Arif Gosita mengenai kewajiban-kewajiban korban antara lain:

1) Tidak dibenarkan melakukan tindakan-tindakan pembalasan main hakim sendiri yang membuat pelaku menderita mental, fisik, sosial.

tolbid. HIm. 75.

"J.E. Sahetapy. Op. Cit. Hlm. 105. 
2) Berpartisipasi dengan masyarakat mencegah adanya korban lebih banyak.

3) Mencegah kehancuran si pembuat korban baik oleh diri sendiri maupun oleh orang lain.

4) Ikut berpartisipasi dengan masyarakat serta membina pelaku korban.

5) Bersedia dibina atau membina diri sendiri untuk tidak menjadi korban lagi.

6) Tidak menuntut ganti kerugian yang tidak sesuai dengan kemampuan pembuat korban.

7) Memberi kesempatan pada pembuat korban untuk mengganti kerugian sesuai dengan kemampuannya.

8) Menjadi saksi bila tidak membahayakan diri sendiri dan ada perlindungan keamanan untuk dirinya. ${ }^{12}$

Demikian beberapa macam hak dan kewajiban korban yang perlu mendapat perhatian untuk dipertimbangkan manfaatnya diatur dalam peraturan/perundang-undangan demi keadilan dan ketertiban umum.

\section{Penanggulangan dan Penyelesaian Korbản dalam Ganti Rugi}

Penanggulangan dan penyelesaian permasalahan korban dalam ganti rugi bukanlah suatu yang mudah karena unsurunsur sosial yang negatif dapat mempengaruhi orang melakukan suatu perbuatan yang sukar untuk dirubah. Oleh sebab itu usaha mengatasi permasalahn korban ganti rugi harus konseptual, mempunyai perencanaan strategi dan taktik dalam pelaksanaannya.

Dalam pelaksanaan penanggulangan ganti rugi harus diusahakan adanya kesediaan dan semangat untuk bekerja sama, mengkoordinasi dan dikoordinasi, mengusahakan keterpaduan dalam berpandangan dan kegiatan memperhatikan kesederhanaan yang efektif untuk menciptakan situasi dan kondisi yang memperlancar usaha.

Langkah yang harus diambil dalam usaha penanggulangannya dan menyelesaikan pelaksanaan ganti rugi agar tidak menimbulkan korban ada beberapa tahapan yang harus dilakukan antara lain: Pertama, mengusahakan pemahaman masalah. Langkah pertama yang harus dilakukan sebelum melakukan pencegahan, penindakan dan penyelesaian suatu korban, maka harus memahaminya dengan tepat serta menganalisanya, terutama faktor-faktor penghambat dan pendukungnya. Yang harus dipahami terutama sebagai landasan adalah:

1. Individu-individu yang terlibat dalam eksistensi suatu victimisasi struktural. Dari individu-individu ini diperhatikan secara khusus mereka yang berpengaruh di lingkungannya (besar atau kecil), dalam berbagai bidang kehidupan dan penghidupan.

2. Kemudian perlu dipahami situasi dan kondisi mereka yang menghambat atau mendukung mereka terlibat dalam suatu victimisasi struktural serta cara mendekati

${ }^{12}$ Arif Gosita. Op. Cit. HIm. 18. 
mereka yang komunikatif persuasuf dalam rangka usaha-usaha pencegahan (general dan spesial).

3. Usaha-usaha pencegahan, pembinaan dan pengawasan sosial dalam menghadapi victimisasi struktural serta akibat, pengaruh, efektifitasnya terhadap yang bersangkutan.

4. Hak dan kewajiban mereka yang terlibat dalam eksistensi suatu victimisasi struktural. ${ }^{13}$

Kedua, mengusahakan pencegahan victimisasi struktural. Dengan bekal pandangan, pemikiran yang tepat dikembangkan dan ditingkatkan usaha-usaha pencegahan victimisasi struktural. Usaha pencegahan harus lebih diutamakan. Alasannya adalah:

1. Tindakan pencegahan adalah lebih sederhana dan baik daripada tindakan represi, koreksi, rehabilitasi dan sebagainya, sebabnya :

a). Tidak selalu memerlukan suatu organisasi yang rumit dan birokrasi yang merupakan peluang penyalahgunaan kekuasaan.

b). Lebih ekonomis bila dibandingkan dengan usaha-usaha represi, koreksi dan rehabilitasi dapat dilakukan sendiri juga.

2. Tindakan pencegahan tidak perlu menimbulkan akibat yang negatif, sebabnya:

a). Tidak menimbulkan korban stigmatisasi, pengasingan dan permusuhan. b). Tidak menimbulkan pelanggaran hak dan kewajiban asasi seseorang, (kecuali dalam usaha-usaha prevensi spesial).

3. Usaha-usaha pencegahan dapat mempererat kerukunan dan meningkatkan rasa tanggungjawab terhadap sesama manusia dalam berbagai bidang kehidupan dan penghidupan jika dilakukan bersama. ${ }^{14}$

a). Mengambil tindakan dan penyelesaian victimisasi struktural

Masalah pengambilan tindakan dan penyelesaian permasalahan merupakan bagian yang terberat dalam penanggulangan victimisasi struktural. Faktor penghambat dan pendukungnya perlu dicari dan dipahami untuk dijadikan bahan penyusunan pola kebijakan penanganan permasalahan victimisasi. Akan dikemukakan di sini beberapa masalah yang berkaitan, yang perlu diperhatikan dan ditangani sebagai berikut :

1. Hambatan yang berkaitan dengan masalah victimisasi struktural ini adalah individu-individu yang terlibat pada eksistensi victimisasi struktural tersebut (secara aktif maupun pasif). Oleh sebab itu, diperlukan suatu pengertian, pemahaman yang tepat mengenai mereka sebelum bertindak. Dalam pengambilan tindakan ini dapat berupa pembinaan, peringatan, pemberian hukuman, dan pelaksanaan hukuman yang diancamkan. Hal ini berkaitan dengan pelaksanaan sistem peradilan

\section{${ }^{13} /$ bid. \\ ${ }^{14} /$ bid.}


pidana yang berkaitan erat dengan masalah-masalah kekuasaan dan keadilan. Pelaksanaan kekuasaan dan keadilan yang tidak berlandaskan pada citra yang tepat mengenai manusia dapat menimbulkan suatu victimisasi struktural. Oleh sebab itu, harus diusahakan pencegahannya antara lain, pencegahan pelaksanaan kekuasaan, kekuatan, wewenang individu pada atau kelompok tertentu yang berspeksif untuk kepentingan yang mengatur. Pada hakekatnya yang harus diatur, dijamin dan diperjuangkan adalah perspektif kepentingan yang diatur dan bukan perspektif kepentingan yang mengatur. Memang sulit apabila yang berkuasa, sebab yang berkuasa mempunyai kekuatan mental, fisik dan sosial lebih kuat daripada pihak-pihak lain. Misalnya, suatu pemerintahan diktator, raja terhadap rakyatnya, orang tua terhadap anaknya yang masih kecil, suami terhadap istri, guru terhadap murid, majikan terhadap buruhnya dan sebagainya.

2. Unsur-unsur struktural sosial masyarakat tertentu yang dapat mempengaruhi positif tindakan seorang individu berpartisipasi dalam mencegah suatu victimisasi struktural, sebaiknya dapat dikembangkan dan dimanfaatkan. Sedangkan unsurunsur struktur sosial yang mempunyai pengaruh negatif sebaiknya diganti, dihapus.

3. Sudah waktunya membuat pusat-pusat pelayanan korban kejahatan, penyalahgunaan kekuasaan, perlakuan salah, penelantaran anak, dalam rangka menyelesaikan permasalahan korban demi peningkatan perlakuan adil dan pemerataan kesejahteraan rakyat,
Undang-undang yang mengatur kesejahteraan sosial dan kesejahteraan anak.

Para korban suatu victimisasi perlu mendapat pelayanan, bantuan, pendampingan mental, fisik, dan sosial dalam menyelesaikan permasalahan victimisasinya. Apabila bantuan kepada para korban tidak diberikan, ditangguhkan atau dibiarkan menderita, maka pada hakekatnya terjadilah victimisasi struktural yang dapat berakibat victimisasi yang non struktural pada yang bersangkutan.

Mengenai pengaturan ganti rugi dalam KUHAP untuk golongan korban tertentu saja, yang berkaitan dengan suatu sistem struktural tertentu, dan dengan demikian tetap membiarkan adanya penderitaan pada golongan korban yang lain, pada hakekatnya merupakan perwujudan eksistensi suatu victimisasi struktural.

4. Dalam victimisasi perlu ditangani antara lain sebagai berikut:

a). Individu-individu sebagai pelaku untuk kepentingan sendiri atau orang/ kelompok, korporasi, dan sebagainya.

b). Individu atau kelompok sebagai korban.

c). Individu atau kelompok sebagai pengamat/saksi, sebagai pelaku (membiarkan berlangsungnya suatu sistem, situasi dan kondisi yang memungkinkan suatu victimisasi).

d). Pembuat Undang-undang sebagai perumus adanya suatu victimisasi atau sebagai pelaku karena membiarkan adanya suatu peraturan yang menimbulkan penderitaan. 
e). Individu aparat pemerintah sebagai pelaku serta pelaku yang menjalankan tugasnya, sehingga menimbulkan penderitaan pada orang lain.

5. Dalam rangka mengurangi victimisasi struktural, maka sebaiknya semua yang terlibat sedapat mungkin diyakinkan akan keuntungan adanya keterpaduan antara kepentingan pribadi dan kepentingan bersama, keluarga masyarakat dan bangsa, yang manusiawi. Pada mereka perlu ditegaskan, bahwa memperjuangkan kepentingan hak dan kewajiban seseorang itu harus seimbang dan manusiawi. Bahwa menyadarkan, meyakinkan seseorang akan hal ini memerlukan waktu, situasi dan kondisi tertentu, maka sebaiknya dikerjakan sedini mungkin di keluarga dan berbagai sarana pendidikan, pembinaan yang lain.

Dalam rangka usaha penanggulangan dan penyelesaian masalah korban dalam pelaksanaan ganti rugi dapat ditangani melalui aspek yuridisnya, karena hal ini menyangkut permasalahan akibat hukum, jaminan hukum yang berkaitan.

Dalam penanggulangan dan penyelesaian permasalahan korban dan ganti rugi supaya diutamakan perspektif kepentingan yang diatur/dilayani dan bukan perspektif kepentingan yang mengatur/ melayani.

\section{Eksistensi Viktimologi dalam Penyelesaian Ganti Rugi}

Kesepakatan para pihak merupakan hal yang penting agar tidak terjadinya korban karena kedua belah pihak harus menyatakan secara bebas kehendaknya dalam menentukan besarnya uang ganti rugi dan jika kehendak ini tidak dinyatakan secara bebas timbul cacat kehendak dan cacat kehendak ini timbul akibat adanya penyalahgunaan kekuasaan yang menyebabkan timbulnya korban, disinilah kaitan eksistensi Viktimologi dengan penyelesaian pelaksanaan ganti rugi.

Viktimologi yang mengkaji masalah korban karena penyalahgunaan kekuasaan dan hak asasi manusia timbul akibat :

1. Penyalahgunaan proses musyawarah

Penyalahgunaan proses musyawarah yang dilakukan menyimpang dari ketentuan hukum: Proses tersebut lebih menitikberatkan kepada penekanan dan intimidasi. Tindakan ini menurut Agnes W.Toar suatu penyalahgunaan dilakukan oleh pihak korban atau disalahgunakan. Pihak yang menyalahgunakan ialah yang secara aktif melakukan tindakan-tindakan tertentu, sehingga pihak yang lain, pihak yang menyalahgunakan menyetujui perjanjian yang bersangkutan. ${ }^{15}$

Kemudian menurut A.P. Parlindungan: "musyawarah merupakan proses atau kegiatan saling mendengarkan dengan sikap saling menerima pendapat dan keinginan yang didasarkan atas kesukarelaan untuk memperoleh

${ }^{15}$ Agus Witoelar. "Bahan dan Proses Peradilan Pidana." Buletin Informasi. Jakarta. 1990. Hlm. 5. 
kesepakatan mengenai bentuk besarnya ganti rugi". Menurut Moh. Koesnoen di dalam masyarakat ajakan musyawarah ini untuk menyelesaikan suatu masalah sangat kuat sekali, karena di dalam masyarakat segala persoalan harus dipecahkan bersama-sama oleh para anggota-anggotanya atas dasar kebulatan kehendak bersama-sama. ${ }^{16}$

2. Penyalahgunaan Keadaan

Tingkat sosial ekonomi dan pendidikan yang rendah dari responden jelas merupakan suatu keadaan yang kurang menguntungkan baik informasi dari segala aspek maupun kemampuan memahami maksud. Keadaan masyarakat yang demikian disalahgunakan untuk meraih keuntungan pribadi tanpa mengindahkan moral; keadilan dan hukum.

Tindakan ini sebenarnya telah merupakan tindakan penyalahgunaan keadaan karena yang menjadi korban adalah masyarakat dan perusahaan, akibat penyalahgunaan tersebut. Wajar masyarakat menjadi korban, karena dengan bekal pendidikan sekolah dasar, dan sosial ekonominya yang memprihatinkan, serta wawasan berpikir masyarakat tersebut belum begitu cermat.

3. Penyalahgunaan kekuasaan atau kepercayaan dalam pelaksanaan pembayaran ganti rugi

Tidak pernah mempedomani ketentuan-ketentuan, tetapi semua memberikan atas kebijaksanaan sendiri, berbeda halnya apabila pembayaran ganti rugi tersebut sesuai dengan peraturan tentunya tidak menimbulkan masalah dan korban masyarakat serta perusahaan dapat dihindarkan.

4. Penyalahgunaan dalam menerapkan hukum

Korban penyalahgunaan dalam menerapkan hukum terjadi akibat adanya korban yang beritikad baik, tetapi tidak dilindungi oleh hukum.

Akhirnya perusahaan korban dari kasus tersebut di atas karena dalam pelaksanaan pembangunan perumahan, perusahaan memakai fasilitas Bank, dan kemudian dengan adanya sengketa menjadi terganggu pemasaran dalam penjualan rumah-rumah, sedangkan bunga Bank tetap harus dibayar, namun dalam praktek sampai saat ini tidak ada perlindungan hukum tentang korban pengusaha tersebut yang telah memperoleh tanah melalui proses hukum yang sah sesuai dengan Pasal 22 PP No.10/61.

Akibat adanya kelalaian dari aparatur pemerintah tersebut selaku pemegang kekuasaan dalam menentukan ada atau tidaknya surat lain di atas tanah tersebut, mengakibatkan perusahaan menjadi korban, sebenarnya secara yuridis perusahaan dapat menuntut pemerintah dalam masalah pengeluaran surat tersebut, berdasarkan ketentuan Pasal 1365 dan Pasal 1366 KUHPerdata yang menyatakan, setiap orang bertanggungjawab tidak saja untuk

'Moh. Koesnoen. 1979. Bunga Rampai Kriminologi Jakarta: Rajawali. HIm. 44. 
kerugian yang disebabkan karena perbuatannya tetapi juga untuk kerugian yang disebabkan karena kelalaian atau kurang hati-hati. Tetapi dalam hal ini perusahaan lebih menitikberatkan penyelesaian secara damai guna menghindari timbulnya korban dalam bentuk uang yang lebih besar lagi.

Adanya korban di dalam pelaksanaan ganti rugi secara Viktimologi belum ada secara tegas peraturan yang mengatur tentang perlindungan hukum terhadap korban.

Di samping hal tersebut di atas kaitannya dengan Viktimologi dalam penyelesaian pelaksanaan ganti rugi berdasarkan analisis yang telah dilakukan ada beberapa cara penyelesaian yaitu :

1) Pihak-pihak korban diajak bermusyawarah Musyawarah adalah proses atau kegiatan saling mendengar dengan sikap saling menerima pendapat dan keinginan yang didasarkan atas kesukarelaan antara pihak. Kesepakatan mengenai bentuk dan besarnya ganti rugi.

Azas musyawarah, azas kekeluargaan, azas mufakat salah satu proses dalam Viktimologi yang dapat menyelesaikan agar tidak menimbulkan korban bagi masyarakat.

2) Menuntut ke Pengadilan

Penyelesaian pelaksanaan ganti rugi yang menimbulkan korban secara yuridis dapat mempedomani ketentuan Pasal
1365 KUHPerdata yang menyatakan:

Tiap perbuatan melanggar hukum yang membawa kerugian seseorang lain mewajibkan yang karena salahnya menerbitkan kerugian itu mengganti kerugian tersebut.

Pasal KUHPerdata tersebut di atas salah satu upaya saluran hukum yang ditempuh oleh korban adalah menuntut ganti rugi ke Pengadilan Negeri setempat, namun selama proses hukum masih berjalan penyelesaian secara damai masih terbuka.

Penyelesaian secara damai ini dipandang perlu untuk menghilangkan rasa dendam antara satu dengan yang lain, di samping untuk menumbuhkan kerukunan hidup bersama. ${ }^{17}$

\section{Simpulan}

Pengertian korban yang mendasari lahirnya kajian Viktimologi pada awalnya terbatas pada korban kejahatan. Dengan demikian; Viktimologi, bukan saja berkaitan dengan korban kejahatan, tetapi juga ada korban dalam artian perdata. Oleh karena itu, hal yang sangat lazim apabila ilmu ini akan memberikan keseimbangan bagi korban dalam mendapatkan penyelesaian ganti rugi, meskipun masalah ini belum ada pengaturan secara eksplisit dan tegas. Ada dua upaya yang dapat dilakukan kaitannya antara eksistensi Viktimologi dalam penyelesaian pelaksanaan ganti rugi, yakni; Pertama, pihak korban diajak bermusyawarah dan kedua, dituntut melalui pengadilan. $\supset$

${ }^{17}$ Moh. Regina Purba. 1992. Kapita Selecta Kriminologi. Bandung. Alumni.HIm. 49. 
Daftar Pustaka

Arif Gosita. 1983. Masalah Korban Kejahatan. Edisi 1. Jakarta: Akademika Pressindo.

Agus Witoelar. "Bahan dan Proses Peradilan Pidana." Buletin Informasi. Jakarta. 1990.

Gosita, Arif. 1987. Viktimologi dan KUHP Yang Mengatur Ganti Kerugian Pihak Korban. Jakarta: Akademika Presindo.
J.E. Sahetapy. 1987, Viktimologi. Jakarta. Pustaka Sinar Harapan.

Moh. Koesnoen. 1979. Bunga Rampai Kriminologi Jakarta: Rajawali.

Separovic. 1985.Victim's. USA: D.C.Health and Company.

Wolfgang. 1979. "Justice for Victim's of Crime." - Presented at a Seminar on Criminologi at Indonesia. 